\title{
Case of pneumomediastinum due to alveolar rupture following endotracheal intubation
}

\author{
Sri Lakshmi Sathiyaseelan, ${ }^{1}$ Narayanasamy Senthil, ${ }^{2}$ Priyadarshini Varadaraj ${ }^{3}$
}

'Postgraduate, Department of General Medicine, Sri Ramachandra Medical College and Research Institute, Sri Ramachandra University, Chennai, Tamil Nadu, India ${ }^{2}$ Professor,Department of General Medicine, Sri Ramachandra Medical College and Research Institute, Sri Ramachandra University, Chennai, Tamil Nadu, India ${ }^{3}$ Assistant Professor, Department of General Medicine, Sri Ramachandra Medical College and Reasearch Institute, Sri Ramachandra University, Chennai, Tamil Nadu, India

\section{Correspondence to}

Dr Priyadarshini Varadaraj, priyavaradaraj@gmail.com

Accepted 16 September 2018

\section{DESCRIPTION}

A 57-year-old woman presented to the outpatient department with complaints of shortness of breath and fever for the past 2 days. She had no known comorbidities. She was admitted in intensive care unit (ICU) in view of type 1 respiratory failure. Initial chest X-ray showed bilateral lower zone non-homogenous opacity (figure 1A). She was initially managed with antibiotics and non-invasive ventilation. However, due to worsening respiratory failure and metabolic acidosis, patient was intubated. Postintubation, patient was connected to a ventilator in volume control mode with fraction of inspired oxygen of 90\%, Positive end expiratory pressure (PEEP) of 10, tidal volume of $350 \mathrm{~mL}$, respiratory set rate of 20 and the ratio of duration of inspiration to the duration of expiration (I:E ratio) of 1:3.3. Chest X-ray repeated following intubation showed features suggestive of pneumomediastinum (figure 1B). The CT thorax done post intubation showed pneumoprecardium (figure $2 \mathrm{~A}$ ) and pneumomediastinum extending up to the neck (figure $2 \mathrm{~B}$ ). No tracheal or oesophageal injury was observed in the CT. Furthermore, there was no bullae in the lung as confirmed by the radiologist. A screening CT abdomen was also done, which did not show any organ perforation. A confirmatory bronchoscopy was also done, which did not show any rent in the trachea. Furthermore, she was managed conservatively and the pneumomediastinum resolved spontaneously after 4 days as shown in the repeat chest X-ray (figure 2C). Patient's non-bronchoalveolar lavage and bronchioalveolar lavage culture showed Acinetobacter species, which is being the cause of infection in this patient.

Pneumomediastinum is the collection of air or any gas in the mediastinum. It can be caused due to intrathoracic injury to the trachea, oesophagus,

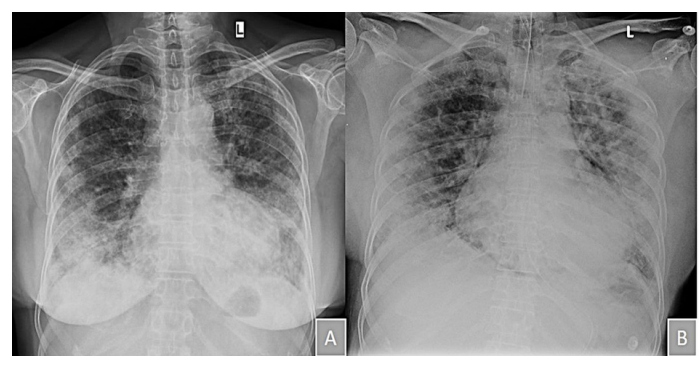

Figure 1 (A) Chest X-ray done on the day of admission showing bilateral lower zone non-homogenous opacity. (B) Chest X-ray done postendotracheal intubation showing pneumoprecardium.

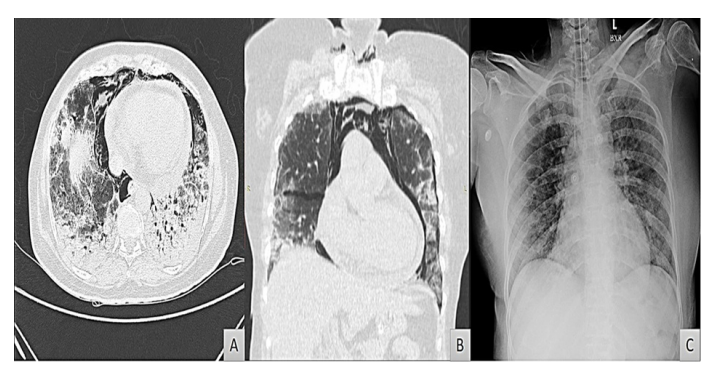

Figure 2 (A) Axial section of CT chest showing pneumoprecardium sign. (B) Coronal section of CT chest showing pneumomediastinum extending above. (C) Chest X-ray done on fourth day of intubation showing spontaneous resolution of the pneumomediastinum.

lung or pleural space and extra thoracic injury-like trauma, rib fracture and intraperitoneal or retroperitoneal organ rupture. Among the intrathoracic causes, the most common cause of pneumomediastinum following endotracheal intubation is tracheal injury ( 1 in 65 000) followed by oesophagus. ${ }^{1}$ Case reports reported in literature has shown alveolar rupture as a cause of pneumomediastinum due to Valsalva manoeuvre, pulmonary function test in asthmatics. However, pneumomediastinum due to alveolar rupture following endotracheal intubation has not been reported.

The signs of pneumomediastinum are pneumoprecardium as shown in our case, ring around the artery sign, continuous diaphragm sign tubular artery sign or extra pleural sign.

The possible mechanism of alveolar rupture in the given setting is explained by Macklin et $a l^{2}$ in the 1940s. This article explains that when there is injury to the lung, there is inability of the fluid rich tissue of the vascular sheath that lies beneath the marginal alveoli to expand, which can weaken or remove the marginal alveolar base support, leading to alveolar rupture and air leakage into vascular sheaths. Hence, overdistension of the alveoli and inadequate expansion of the vessel lumen with very negative pressure in the interstial space creating pressure gradient between alveoli and the perivascular sheath can lead to rupture of the basal alveoli (marginal type).

The most probable cause of pneumomediastinum in this case is an alveolar rupture probably due to acute pneumonia. Case reports showing that children can develop spontaneous pneumomediastinum following pneumonia shows the need for study in adults for the same. ${ }^{3}$ 


\section{Learning points}

Spontaneous alveolar rupture can occur when a pressure gradient exist between the alveoli and the perivascular sheath. Hence, in these cases, even a mild exertion can lead to pneumomediastinum.

- In patients who have developed pneumomediastinum, it is ideal to support them with low PEEP to avoid further worsening.

Contributors All authors collected the case details. SLS prepared the manuscript with inputs from NS and PV. All authors approved the manuscript, and all authors agree to be accountable for all aspects of the work in ensuring that questions related to the accuracy or integrity of any part of the work are appropriately investigated and resolved.
Funding The authors have not declared a specific grant for this research from any funding agency in the public, commercial or not-for-profit sectors.

Competing interests None declared.

Patient consent Next of kin consent obtained.

Provenance and peer review Not commissioned; externally peer reviewed.

\section{REFERENCES}

1 Óvári A, Just T, Dommerich $\mathrm{S}$, et al. Conservative management of post-intubation tracheal tears-report of three cases. J Thorac Dis;2014:E85-E91.

2 Macklin MT, et al. Malignant interstitial emphysema of the lungs and mediastinum as an important occult complication in many respiratory diseases and other conditions: An interpretation of the clinical literature in the light of laboratory experiment. Medicine 1944;23:281-358

3 Tortajada-Girbés M, Moreno-Prat M, Ainsa-Laguna D, et al. Spontaneous pneumomediastinum and subcutaneous emphysema as a complication of asthma in children: case report and literature review. Ther Adv Respir Dis 2016;10:402-9.

Copyright 2018 BMJ Publishing Group. All rights reserved. For permission to reuse any of this content visit

http://group.bmj.com/group/rights-licensing/permissions.

BMJ Case Report Fellows may re-use this article for personal use and teaching without any further permission.

Become a Fellow of BMJ Case Reports today and you can:

- Submit as many cases as you like

- Enjoy fast sympathetic peer review and rapid publication of accepted articles

- Access all the published articles

- Re-use any of the published material for personal use and teaching without further permission

For information on Institutional Fellowships contact consortiasales@bmjgroup.com

Visit casereports.bmj.com for more articles like this and to become a Fellow 